\title{
Yield and weed suppression by pigeon pea cultivars in rotation with tomato and pepper
}

\author{
Nelson Semidey and Angel Bosques-Vega
}

J. Agric. Univ. P.R. 83(1-2):55-64 (1999)

\begin{abstract}
Two field experiments were conducted at the Lajas and Juana Diaz Agricultural Experiment Substations to evaluate seven pigeon pea [Cajanus cajan (L.) Huth] cultivars for yields, weed suppression, and the impact on the subsequent tomato [Lycopersicon lycopersicum (L.) Karst. ex Farw] and pepper (Capsicum annuum L.) plantings. Trials started in July 1993 and ended in June 1995. Treatments consisted of incorporation of plant stubble from seven different pigeon pea cultivars into the soil. Cultivars Kaki, 2BBushy, PR 147, Blanco de Yauco, Guerrero, Cortada, and Line 84 were grown from mid-July to late January of the following year. Tomato and pepper seedlings were transplanted into the plots six weeks after incorporation of whole plant stubble of pigeon pea. Pod yields of all cultivars, except Guerrero, were higher in Juana Díaz than those of Lajas. Compared with control plots, pigeon pea did not affect weed densities at Lajas, but at Juana Díaz all cultivars reduced weed densities in tomato and pepper grown in 1994 and 1995. The weed species suppressed by pigeon pea in the tomato planting at Juana Díaz were Amaranthus dubius Mart. ex Thell, Cyperus rotundus L., Echinochloa colona (L.) Link, and Trianthema portulacastrum $L$.
\end{abstract}

Key words: allelopathy, pigeon pea, weed suppression

RESUMEN

Rendimiento y supresión de malezas por cultivares de gandul en rotación con tomate y pimiento

Desde julio de 1993 hasta junio de 1995 se realizaron dos experimentos de campo en las Subestaciones de la Estación Experimental Agrícola de Lajas y Juana Díaz para evaluar el rendimiento, la supresión de malezas y el impacto de siete cultivares de gandul [Cajanus cajan (L.) Huth] sobre siembras subsiguientes de tomate y pimiento. Los tratamientos consistieron en la incorporación al suelo de los rastrojos de plantas de siete cultivares de gandul. Los cultivares de gandul Kaki, 2B-Bushy, PR 147, Blanco de Yauco, Guerrero, Cortada y la Línea 84 se cultivaron desde mediados de julio hasta finales de enero del siguiente año. Las plántulas de tomate y pimiento se trasplantaron seis semanas después de la incorporación de los rastrojos del gandul. En ambos años, el rendimiento promedio en vaina de todos los cultivares de gandul, excepto Guerrero, fueron más altos en Juana Díaz que en Lajas. Al compararse con las parcelas control, los cultivares de gandul

Manuscript submitted to Editorial Board 11 February 1998.

'Associate Weed Scientist, Crop Protection Department, P.O. Box 9030, Mayagüez, P.R. 00681-9030.

${ }^{3}$ Associate Researcher, Horticulture Department, Box 506, Isabela, P.R. 
no afectaron las densidades de malezas en Lajas, pero todos los cultivares redujeron las densidades de malezas en siembras de tomate y pimiento en Juana Diaz en 1994 y 1995. Amaranthus dubius, Cyperus rotundus, Echinochloa colona, y Trianthema portulacastrum fueron las especies de malezas suprimidas en la siembra de tomate posterior a la siembra del gandul en Juana Díaz.

\section{INTRODUCTION}

Pigeon pea has been the most widely cultivated edible legume in Puerto Rico. Local production for 1995-96 was $454 \mathrm{t}$ of fresh pigeon pea with a farm value of $\$ 0.87$ million (Departamento de Agricultura, 1997). This crop has been recognized as a strong competitor for weeds. Several cultivars and some experimental lines had no yield response to different weed control treatments (Abrams et al., 1974). Late weed suppression was proposed as the mechanism by which pigeon pea could overcome weed competition in plots with initial poor weed control (Semidey and Almodovar, 1987).

Studies have demonstrated the benefits of pigeon pea rotation in crop production systems (Bosque-Fernández, 1986; Dalal and Quilt, 1977; Hepperly et al., 1992). The allelopathic effects of pigeon peas on weeds was demonstrated in Puerto Rico by Hepperly and Díaz (1983) and Semidey et al. (1994). Under greenhouse conditions, germinating weeds were inhibited for at least two months after soil incorporation of pigeon pea leaf litter (Hepperly et al., 1992). In a crop rotation study, cucumber yields were increased with the addition of pigeon pea residue before soil preparation for planting (Bosque-Fernández, 1986).

In addition to weed suppression, another advantage attributed to pigeon pea is that no fertilization is required for normal plant growth (Dalal and Quilt, 1977). Furthermore, nitrification inhibition, which prevents nitrogen loss, has been attributed to exudates from allelopathic plant species such as the pigeon pea (Rice, 1992). Pigeon pea can also be used by vegetable growers who have not used crop rotation.

The agronomic performance of several pigeon pea cultivars and new breeding lines has been evaluated successfully for many years in Puerto Rico. In spite of the benefits that may be derived from pigeon pea plantings, certain growers have complained of reduced vegetable yields after cropping with pigeon pea. ${ }^{4}$ However, there is no experimental evidence to support such arguments. Allelopathic plant residues can be integrated in crop production systems to supplement early practices of weed control. Research is needed to determine the compatibility of new pigeon pea cultivars in rotation with vegetable crops that may follow. 
The objective of this study was to evaluate pigeon pea potential in a rotation scheme for yields, weed suppression, and potential impact on tomato and pepper.

\section{MATERLALS AND METHODS}

Pigeon pea cultivars Kaki, 2 B Bushy, PR 147, Blanco de Yauco, Guerrero, Cortada, and Line 84 were field planted at the Lajas and Juana Díaz Agricultural Experiment Substations in a rotation program of two years (Table 1). The soil at Lajas is a Typic Haplusterts, fine montmorillonitic, isohyperthermic, with $\mathrm{pH} 6.4$ and $1.4 \%$ organic matter, whereas at Juana Díaz the soil is classified as a Cumulic Haplustolls, fine-loamy, mixed, isohyperthermic with $\mathrm{pH} 7.6$ and $1.9 \%$ organic matter.

At both locations for the two years, plots consisted of three pigeon pea rows that were $4.6 \mathrm{~m}$ long and $0.9 \mathrm{~m}$ apart. Seeds were spaced 30 $\mathrm{cm}$ in the row for a total of 15 pigeon pea plants per row. Plots not planted with pigeon peas but handweeded from three to nine weeks after planting were included as controls. A randomized complete block design with eight treatments (seven pigeon pea cultivars and control) and eight replications per treatment were used. Pigeon pea plots were cultivated mechanically for the first six weeks to prevent weed-seed production and excessive interference. Mature pigeon pea pods were harvested from mid-December to late January in both years.

After pigeon pea harvesting in January of the following year, four of the eight replications of the whole experimental area were used to study the impact of pigeon pea on tomato plants, and four to study the

TABLE 1.-Two-year rotation program with pigeon pea cultivars, incorporation dates of their respectives stubble into soil, and planting dates for tomato and peppers that followed pigeon pea at Juana Diaz and Lajas Substations.

\begin{tabular}{lcccc}
\hline & $\begin{array}{c}\text { Planting date } \\
\text { for pigeon pea } \\
\text { cultivars }\end{array}$ & $\begin{array}{c}\text { Incorporation } \\
\text { of pigeon pea } \\
\text { stubble }\end{array}$ & \multicolumn{2}{c}{ Planting date } \\
\hline Juana Díaz: & & & Tomato & Pepper \\
First year & 14 July 1993 & 24 January 1994 & 4 March 1994 & 3 March 1994 \\
Second year & 23 July 1994 & 27 January 1995 & 10 March 1995 & 16 March 1995 \\
Lajas: & & & & \\
$\begin{array}{l}\text { First year } \\
\text { Second year }\end{array}$ & 12 July 1993 & 27 January 1994 & 3 March 1994 & 1 March 1994 \\
\hline
\end{tabular}

Whole plant and leaf litter was disked into soil after harvesting of pigeon pea pods. 
impact on pepper plants. Prior to tomato and pepper plantings, the selected plots were disked twice, each cut in the opposite direction to incorporate pigeon pea stubble. At both locations, tomato cv. Duke and pepper $\mathrm{cv}$. Key Largo seedlings were transplanted as indicated in Table 1. Three rows, $90 \mathrm{~cm}$ apart, were planted with both crops. Plant spacing in the row was $45 \mathrm{~cm}$ and $30 \mathrm{~cm}$ for tomato and pepper, respectively.

In pepper, weeds were controlled with fluazifop $(0.28 \mathrm{~kg}$ ai $/$ ha, over the top of the plants) and paraquat $(0.47 \mathrm{~kg}$ ai/ha, directed spray) the fourth week after transplanting and mechanically cultivated thereafter. Metribuzin ( $0.35 \mathrm{~kg}$ ai/ha) and fluazifop $(0.28 \mathrm{~kg}$ ai $/ \mathrm{ha})$ were applied sequentially over the top of the tomato plants two and three weeks, respectively, after transplanting.

Weed density (plants per $0.5 \mathrm{~m}^{2}$ ) and crop stand (plants per 4.6 -m row) were evaluated in the center rows of each plot three weeks after transplanting (WAT) the tomato and pepper seedlings. Five plants each of tomato and pepper were collected at random at six WAT for dry weight and plant height determination. Tomato and pepper yields were not recorded during 1994 . Both crops were severely affected by insects, and tomato was also affected by viral diseases.

For the second year, the same plots were disked as previously indicated and seedbeds prepared for pigeon pea planting. Tomato and pepper plantings were managed as the previous year. In search for crop tolerance to virus, tomato cv. Heatwave instead of cv. Duke was transplanted in 1995. Fruits within the center row were harvested from midMay to late July 1995 for tomato and pepper yields.

Data from pigeon pea harvestings, crop stand, plant height, and dry weight were combined over the years and locations, and subjected to an analysis of variance (ANOVA). Since weed species were different at each location, data on weed densities were not combined over locations. Data on weed density for individual weed species from the control and the combined mean of the seven cultivars were subjected to an independent ANOVA. Means were separated by LSD at the $\mathrm{P} \leq 0.05$. Data of years were combined when ANOVA was nonsignificant $(P>0.05)$.

\section{RESULTS AND DISCUSSION}

\section{Yield of pigeon pea cultivars}

Cultivar by year interaction was nonsignificant ( $P=0.32$ ); thus, means of two years is presented. Cultivar by location interaction was significant $(\mathrm{P}<0.05)$ for pigeon pea yields (Table 2 ). Pod yields of all pigeon pea cultivars, except Guerrero, were higher at Juana Díaz than those at Lajas over the two years of the experiments' duration. At 
TABLE 2.-Fresh pod yield of pigeon pea cultivars at Lajas and Juana Diaz'.

\begin{tabular}{|c|c|c|}
\hline \multirow[b]{2}{*}{ Pigeon pea cultivar } & \multicolumn{2}{|c|}{ Location } \\
\hline & Lajas & Juana Díaz \\
\hline & $\ldots \ldots$ & ...... \\
\hline Kaki & 5,680 & 6,535 \\
\hline 2 B Bushy & 4,600 & 7,510 \\
\hline PR 147 & 4,030 & 9,325 \\
\hline Blanco de Yauco & 5,455 & 10,650 \\
\hline Guerrero & 5,015 & 4,160 \\
\hline Line 84 & 4,650 & 6,290 \\
\hline Cortada & 4,070 & 8,610 \\
\hline $\operatorname{LSD}(0.05)^{2}$ & $\ldots .$. & $\ldots \ldots$ \\
\hline $\operatorname{LSD}(0.05)^{3}$ & $\ldots$ & $\ldots \ldots$ \\
\hline
\end{tabular}

'Average of two years (1994-1995) and eight replications per location.

'LSD to compare means in one location.

"LSD to compare means between the two locations.

Juana Díaz, cultivars Blanco de Yauco and PR 147 produced the highest yields. Cortada also produced higher yields than Guerrero, Kaki, and Line 84. At Lajas, Kaki and Blanco de Yauco produced higher yields than PR 147 and Cortada.

\section{Crop growth}

Analysis of variance was nonsignificant for growth parameters evaluated in tomato and peppers (Table 3). Crop stand, dry weight, and plant height of tomato and pepper seedlings were not significantly affected by pigeon pea cultivars. In further studies conducted in 1995-96, we found that weed dry weight, as well as tomato yield, was lower in plots where whole pigeon pea stubble was removed, or where leaf litter plus the root system was added to the plot (Semidey and Medina, 1996). Therefore, we theorized that allelopathic chemicals may be produced and liberated from pigeon pea foliage during plant growth or may be derived from leaf litter decomposition after reaching the soil.

\section{Pigeon pea-pepper cropping sequence}

Year by cultivar interaction was nonsignificant for data on weed density at Lajas $(P=0.25)$ and Juana Díaz $(P=0.40)$.

Lajas. Mean weed density in 1994 (185 plants per $0.5 \mathrm{~m}^{2}$ ) was higher $(\mathrm{P}=0.0001)$ than in 1995 (38 plants per $\left.0.5 \mathrm{~m}^{2}\right)$; thus, data of each year are considered independently. Wild poinsettia (Euphorbia 
TABLE 3.-Statistical summary for crop stand, dry weight, and plant height of tomato and pepper grown in rotation with pigeon peas, averaged over two locations and two years of experiments.'

\begin{tabular}{lccc}
\hline Growth parameter & Range & F-value & $\mathrm{P}<\mathrm{F}$ \\
\hline Crop stand & (no. per 4.6-m row) & & \\
$\quad$ Tomato & 13.6 to 14.5 & 1.20 & 0.30 \\
Pepper & 14.6 to 14.9 & 0.91 & 0.99 \\
Dry weight & (g/plant) & & \\
Tomato & 4.1 to 5.6 & 1.44 & 0.21 \\
Pepper & 3.9 to 4.0 & 0.63 & 0.72 \\
Plant height & (cm) & & \\
Tomato & 29.0 to 31.0 & 2.05 & 0.09 \\
Pepper & 24.8 to 28.8 & 0.41 & 0.88 \\
\hline
\end{tabular}

'Crop stand was recorded three weeks after transplanting; dry weight and plant height was recorded at six weeks.

heterophylla L.) and jungle rice [Echinocloa colona (L.) Link] were the predominant weeds in this area. Compared with the control, pigeon pea cultivars did not significantly affect weed densities and yield of the subsequent pepper planting (Table 4). Pigeon pea incorporation in the clay

TABLE 4.-Total weed density after two years (1994-1995) of pigeon pea-pepper cropping sequence and yield of pepper at Lajas and Juana Diaz.

\begin{tabular}{|c|c|c|c|c|c|}
\hline \multirow{2}{*}{$\begin{array}{l}\text { Pigeon pea } \\
\text { cultivar }\end{array}$} & \multicolumn{2}{|c|}{ Weed density-Lajas' } & \multirow{2}{*}{$\begin{array}{l}\text { Pepper } \\
\text { yield }\end{array}$} & \multirow{2}{*}{$\begin{array}{l}\text { Weed density } \\
\text { Juana Diaz }\end{array}$} & \multirow{2}{*}{$\begin{array}{l}\text { Pepper } \\
\text { yield }^{2}\end{array}$} \\
\hline & 1994 & 1995 & & & \\
\hline & \multicolumn{2}{|c|}{ plants per $0.5 \mathrm{~m}^{2}$} & $\mathrm{~kg} / \mathrm{ha}$ & plants per $0.5 \mathrm{~m}^{2}$ & $\mathrm{~kg} / \mathrm{ha}$ \\
\hline Kaki & 152 & 26 & 12,390 & 95 & 19,400 \\
\hline 2 B Bushy & 164 & 31 & 16,880 & 126 & 15,240 \\
\hline PR 147 & 117 & 36 & 14,040 & 91 & 13,920 \\
\hline $\begin{array}{l}\text { Blanco de } \\
\text { Yauco }\end{array}$ & 176 & 42 & 24,800 & 123 & 21,750 \\
\hline Guerrero & 177 & 35 & 12,160 & 113 & 11,750 \\
\hline Line 84 & 139 & 35 & 15,810 & 78 & 17,830 \\
\hline Cortada & 124 & 37 & 14,700 & 98 & 14,780 \\
\hline Control & 126 & 59 & 18,140 & 219 & 18,190 \\
\hline $\operatorname{LSD}(0.05)$ & NS & NS & NS & 52 & NS \\
\hline
\end{tabular}

'Weed density three weeks after planting pepper in plots previously grown with corresponding pigeon pea cultivars.

Pepper yield was recorded in 1995. 
soil of Lajas was somewhat more difficult than in the loamy soil of Juana Díaz, all of which probably influenced the efficacy of allelopathic substances released from pigeon pea stubble.

Juana Díaz. Mean weed density in 1994 (115 plants per $\left.0.5 \mathrm{~m}^{2}\right)$ was not significantly different $(\mathrm{P}=0.55)$ from that of 1995 (121 plants per $0.5 \mathrm{~m}^{2}$ ); thus, data were combined over the two years. All pigeon pea cultivars provided lower weed density than the control (Table 4). The lower weed densities demonstrated the allelopathic effect of pigeon pea cultivars on weed populations. Pepper yield was not significantly affected by the pigeon pea cultivars at this location. This result is not in agreement with the suspected arguments of reduced yields due to pigeon pea rotation. Pigeon pea rotation represents an alternative strategy for weed suppression with no major risks for pepper production at this location.

\section{Pigeon pea-tomato sequence}

Year by cultivar interaction was nonsignificant for data on weed density at Lajas $(\mathrm{P}=0.96)$ and Juana Díaz $(\mathrm{P}=0.31)$.

Lajas. Weed densities were not significantly different among the pigeon pea cultivars and the control in either year of tomato planting (Table 5). As in the pepper experiment, pigeon pea did not affect wild

TABLE 5.-Total weed density after two years (1994 -1995) of cropping sequence and yield of tomato at Lajas and Juana Díaz.

\begin{tabular}{|c|c|c|c|c|c|c|}
\hline \multirow{2}{*}{$\begin{array}{l}\text { Pigeon pea } \\
\text { cultivar }\end{array}$} & \multicolumn{2}{|c|}{$\begin{array}{c}\text { Weed density } \\
\text { Lajas' }\end{array}$} & \multirow{2}{*}{$\begin{array}{l}\text { Tomato } \\
\text { yield }^{2}\end{array}$} & \multicolumn{2}{|c|}{$\begin{array}{l}\text { Weed density } \\
\text { Juana Díaz }\end{array}$} & \multirow{2}{*}{$\begin{array}{l}\text { Tomato } \\
\text { yield }{ }^{2}\end{array}$} \\
\hline & 1994 & 1995 & & 1994 & 1995 & \\
\hline & \multicolumn{2}{|c|}{ plants per $0.5 \mathrm{~m}^{2}$} & $\mathrm{~kg} / \mathrm{ha}$ & \multicolumn{2}{|c|}{ plants per $0.5 \mathrm{~m}^{2}$} & $\mathrm{~kg} / \mathrm{ha}$ \\
\hline Kaki & 123 & 18 & 9,400 & 87 & 66 & 8,450 \\
\hline 2 B Bushy & 90 & 22 & 12,240 & 71 & 71 & 8,940 \\
\hline PR 147 & 119 & 17 & 8,980 & 78 & 60 & 6,560 \\
\hline $\begin{array}{l}\text { Blanco de } \\
\text { Yauco }\end{array}$ & 111 & 21 & 10,940 & 81 & 74 & 6,360 \\
\hline Guerrero & 123 & 17 & 9,090 & 51 & 68 & 9,890 \\
\hline Line 84 & 116 & 20 & 9,580 & 120 & 90 & 3,870 \\
\hline Cortada & 93 & 13 & 7,350 & 104 & 77 & 6,430 \\
\hline Control & 143 & 29 & 14,470 & 269 & 204 & 7,330 \\
\hline $\operatorname{LSD}(0.05)$ & NS & NS & 3,850 & 60 & 55 & NS \\
\hline
\end{tabular}

${ }^{1}$ Weed density three weeks after planting tomato in plots previously grown with corresponding pigeon pea cultivars.

2Tomato yield was recorded in 1995 . 
poinsettia and junglerice, the predominat weeds at Lajas. Tomato yields with $2 \mathrm{~B}$ Bushy and Blanco de Yauco were not different from those of the control. Yields from plots that were planted with Kaki, PR 147, Guerrero, Cortada, and Line 84 were lower than in the control. These cultivars had negative impact on tomato yield. No detrimental effect was recorded during the early growth of tomato plants (crop stand, dry weight and height) but a reduction in yield was measurable when these pigeon pea cultivars preceded the tomato planting.

Juana Díaz. Mean weed density in 1994 (108 plants per $\left.0.5 \mathrm{~m}^{2}\right)$ was higher $(\mathrm{P}=0.02)$ than in 1995 ( 89 plants per $\left.0.5 \mathrm{~m}^{2}\right)$; for this reason, data of each year are presented independently. In the tomato plantings of 1994 and 1995, weed densities in the control plots were higher than in plots that were planted with all seven pigeon pea cultivars (Table 5). Cultivar Guerrero was the most suppressive cultivar of the trial in 1994 with $81 \%$ weed reduction, compared with the control. Guerrero also demonstrated greater weed suppression than Line 84 . All seven pigeon pea cultivars suppressed weed density when compared with the control in the 1995 trial.

In 1995, tomato plants were affected by virus diseases which reduced fruit production. After two pickings, no significant differences in the yield were observed among cultivars and the control.

Response of specific weeds to pigeon pea

Lajas. Weed species that predominated at this site, E. heterophylla and $E$. colona, were not influenced by the pigeon pea cultivars that preceded tomato and pepper during the two-year period of the experiment (Table 6). Allelopathic response from pigeon pea was negligible at this location.

Juana Díaz. E. colona, and T. portulacastrum L. had lower densities in tomato and pepper grown after pigeon pea than tomato and pepper without pigeon pea (Table 4). Pigeon pea suppressed A. dubius by $78 \%$ in tomato. Cleome gynandra L. was not influenced significantly by pigeon pea, neither in pepper nor tomato. Mean density of $C$. rotundus $\mathrm{L}$. was suppressed by pigeon pea in the tomato plantings but this weed was not influenced in the pepper plantings. The results suggest that specific pigeon pea cultivars may provide greater allelopathic potential for certain weed species that could interfere with tomato. Integration of pigeon pea rotations into a management system with tomato may be a possible strategy for the management of weed species affected by pigeon pea. 
TABLE 6.-Mean density of specific weed species three weeks after transplanting tomato and pepper in plots groun with pigeon pea and without pigeon pea, averaged across cultivurs and years.

\begin{tabular}{|c|c|c|c|c|c|c|}
\hline \multirow[b]{2}{*}{ Weed species } & \multicolumn{2}{|c|}{ Mean density in tomato } & \multirow[b]{2}{*}{$\operatorname{LSD}(0.05)$} & \multicolumn{2}{|c|}{ Mean density in pepper } & \multirow[b]{2}{*}{$\operatorname{LSD}(0.05$} \\
\hline & $\begin{array}{c}\text { With } \\
\text { pigeon pea }\end{array}$ & $\begin{array}{l}\text { Without } \\
\text { pigeon pea }\end{array}$ & & $\begin{array}{c}\text { With } \\
\text { pigeon pea }\end{array}$ & $\begin{array}{c}\text { Without } \\
\text { pigeon pea }\end{array}$ & \\
\hline & \multicolumn{2}{|c|}{ Plants per $0.5 \mathrm{~m}^{2}$} & & \multicolumn{2}{|c|}{ plants per $0.5 \mathrm{~m}^{2}$} & \\
\hline \multicolumn{7}{|l|}{ Lajas: } \\
\hline Euphorbia heterophylla & 31 & 46 & NS & 86 & 81 & NS \\
\hline Echinochloa colona & 3 & 10 & NS & 14 & 11 & NS \\
\hline \multicolumn{7}{|l|}{ Juana Díaz: } \\
\hline Amaranthus dubizis & 4 & 18 & 7 & 3 & 6 & NS \\
\hline Cleome gynandra & 7 & 17 & NS & 3 & 7 & NS \\
\hline Cyperus rotundus & 2 & 15 & 8 & 9 & 17 & NS \\
\hline Echinochloa colona & 37 & 128 & 22 & 67 & 136 & 32 \\
\hline Trianthena portulacastrum & 27 & 65 & 21 & 19 & 49 & 20 \\
\hline
\end{tabular}




\section{LITERATURE CITED}

Abrams, R. and F. J. Juliá, 1974. Effect of mechanical, cultural and chemical weed control on yield components of pigeon pea Cajanus cajan (L.) Millsp. J. Agric. Univ. P.R. 58:466-472.

Bosque-Fernández, P. A., 1986. Efecto de residuos de gandul en tres cultivos subsiguientes. M.S. Thesis. University of Puerto Rico, Mayagüez Campus. 42 pp.

Dalal, R. C. and P. Quilt, 1977. Effect of nitrogen, phosphorus, molybdenum and liming on grain yield of pigeon pea [Cajanus cajan (L.) Millsp.]. Proc. Caribbean Food Crop Soc. 13:19-23.

Departamento de Agricultura, 1997. Ingreso bruto y neto de la agricultura de Puerto Rico 1995-96-1996-97. Oficina de Estadísticas Agrícolas, Santurce, P.R.

Hepperly, P., H. Aguilar-Erazo, R. Perez, M. Deus and C. Reyes, 1992. Pigeon Pea and velvet bean allelopathy. Pages 357-370. In Rizvi S. J. H. and V. Rizvi (eds.) Allelopathy: Basic and Applied Aspects. Chapman and Hall, London.

Hepperly, P. R. and M. Día, 1983. The allelopathic potential of pigeon pea in Puerto Rico. J. Agric. Univ. P.R. 67:450-455.

Rice, E. L., 1992. Allelopathic effects on nitrogen cycling. Pages 31-58. In: Rizvi S. J. H. and V. Rizvi (eds.). Allelopathy: Basic and Applied Aspects, Chapman and Hall, London.

Semidey, N. and R. Medina, 1996. Sources of allelopathic chemicals in pigeon pea. Book of Abstracts p. 92 In: First World Congress on Allelopathy. September 16-20, 1996. Cadiz, Spain.

Semidey, N. and L. Almodovar, 1987. Oxyfluorfen: A candidate herbicide for weed control in pigeon peas. J. Agric. Univ P.R. 71:277-285.

Semidey N., L. E. Rivera and R. Medina, 1994. Weed management in a pigeon pea-tomato cropping system. Proc. Ann. Meet. Caribbean Food Crop Soc. 30:273-276. 